\title{
Understanding the Antecedents of Knowledge Sharing: An Organizational Justice Perspective
}

\author{
Bashorat Ibragimova, Sherry D. Ryan, John C. Windsor, \\ and Victor R. Prybutok \\ University of North Texas, Denton, TX, USA
}

\author{
dr.bashorat.ibragimova@gmail.com; sherry.ryan@unt.edu; \\ john.windsor@unt.edu; victor.prybutok@unt.edu
}

\begin{abstract}
Knowledge sharing is an important variable in the knowledge management literature emphasizing the importance of social factors. Recent research has revealed that social-psychological and sociological factors are imperative to knowledge sharing. The theory of reasoned action (TRA) was designed to model how any specified behavior under volitional control is produced by beliefs, attitudes, and intentions towards that behavior. Organizational justice encompasses three dimensions: interactive, procedural, and distributive justice. This study explores knowledge sharing through the lens of organizational justice by empirically testing a model that combined elements from the Theory of Reasoned Action and the Organizational Justice Theory. The study findings show that attitude toward knowledge sharing, subjective norm, and procedural justice have a direct impact on the intention to share knowledge, while distributive and interactional justice influence it indirectly via attitude toward knowledge sharing. Implications for both theory and practice are discussed.
\end{abstract}

Keywords: Knowledge Sharing, Theory of Reasoned Action, Subjective Norm, Procedural Justice, Distributive Justice, Interactional Justice

\section{Introduction}

The informing science framework considers three distinct areas: the informing environment, the delivery system, and the task-completion system. At the foundation of informing science is the notion that data, information and knowledge are interdependent entities that continuously interact with each other (Gackowski, 2012). Nevertheless, there are different views on the nature of knowledge, and these varying perspectives have different implications for organizations seeking to gain a competitive advantage. If knowledge is viewed as a resource, then the organizational efforts focus on 'managing' knowledge similar to managing other factors of production, for example inventory control levels or scheduling deliveries. On the other hand, the process perspective of knowledge includes managing the human side of the equation and identifying ways of facilitat-

Material published as part of this publication, either on-line or in print, is copyrighted by the Informing Science Institute. Permission to make digital or paper copy of part or all of these works for personal or classroom use is granted without fee provided that the copies are not made or distributed for profit or commercial advantage AND that copies 1) bear this notice in full and 2) give the full citation on the first page. It is permissible to abstract these works so long as credit is given. To copy in all other cases or to republish or to post on a server or to redistribute to lists requires specific permission and payment of a fee. Contact Publisher@InformingScience.org to request redistribution permission. ing knowledge exchange. If it is not a

resource to be stockpiled as a factor of production, but rather a meaning to be achieved through sharing in a community (Boland, 1987), then it is imperative to identify factors that contribute to enhancing the informing environment. This study takes this later perspective and explores the individual motivations for knowledge sharing. Specifically, the current research proposes and empiri- 
cally tests a model that combines the Theory of Reasoned Action (TRA) with Organizational Justice Theory and argues that perceptions of organizational justice are crucial building blocks of the knowledge-sharing environment.

Prior research found that TRA developed by Ajzen and Fishbein (1973) is useful in predicting the intention to share knowledge and that social-psychological and sociological factors are crucial to knowledge sharing (Bock, Zmud, Kim, \& Lee, 2005). Applying organizational justice components to knowledge sharing processes, this study posits that knowledge sharing will occur when parties engaged in the process feel that (1) their inputs into the exchange relationship are adequately rewarded by benefits gained, (2) the procedures are fair and just, and (3) they are treated with dignity and respect by other parties. These distributive, procedural, and interactional factors will determine the willingness to engage in the knowledge-sharing partnership. The overall research question is: What impact do the perceptions of organizational justice have on individual attitude, subjective norm, and intentions to share knowledge?

A key contribution of this study is the creation of a theoretical model combining organizational theory and TRA concepts to investigate knowledge sharing behaviors through the lens of equity. Review of the literature shows that this was not previously done. This research provides empirical evidence to support the theoretical argument of the importance of procedural, distributive, and interactional justice to the perception of subjective norms that influence attitudes and intentions to share knowledge. Cohen's (2009) updated informing science framework highlights the fact that the informer is influenced by his or her psychological "fragilities," operating within, and influenced by, the environmental context. This study significantly contributes to the literature by investigating these complexities. The current research shows that the informer (the individual sharing knowledge) is influenced indeed by his or her psychological fragilities in the form of attitudes and subjective norms. The environmental context, in terms of organizational justice, is important in shaping attitudes and influencing knowledge sharing behavior.

The rest of the paper is organized as follows: theoretical background and previous research on knowledge sharing, TRA and Organizational Justice are presented first, followed by the research model and hypotheses, proposing specific relationships between TRA and Organizational Justice constructs and knowledge sharing. Research methodology and data analysis are followed by discussion and implications for practice and research along with conclusions for the paper.

\section{Theoretical Background}

\section{Knowledge Sharing}

The organization serves as a knowledge-integrating institution, integrating the knowledge of many different individuals and groups in the process of producing goods and services. Knowledge processes occur at various levels (individual, group, and collective) in organizations and because there are forces that can potentially lead to negative outcomes and an organization that wants to harness its knowledge needs to transform these "vicious" circles into "virtuous" circles of increasing returns (Garud \& Kumaraswamy, 2005). Knowledge management strategies involve the processes of creating, codifying, and sharing knowledge in order to obtain "the right information, to the right person, in the right place at the right time" (Jean-Paul \& Shih, 2011, p. 3).

A vital element in the success of knowledge management is knowledge sharing (Park, Son, Lee, \& Yun, 2009). Knowledge sharing was researched through a variety of theoretical lens. Sociological theories such as social capital and social cognitive theories were used to investigate knowledge sharing in virtual and digitally enabled communities (Chiu, Hsu, \& Wang, 2006; Robert, Dennis, \& Ahuja, 2008). Various organizational theories were used as well. For example, Ryan, Windsor, Ibragimova, and Prybutok (2010), using the knowledge-based view of the firm, 
Ibragimova, Ryan, Windsor, \& Prybutok

found that organizational technology, strategic, and decision practices lead to knowledge sharing. Still other research has utilized psychological-based theories when investigating knowledge sharing. Personality traits and the level of extrinsic and intrinsic motivation were investigated in conjunction with knowledge sharing (Cho, $\mathrm{Li}, \& \mathrm{Su}, 2007)$. TRA, which originated in the psychology discipline, were used also as a theoretical basis to investigate knowledge sharing. In a study of 113 Information Systems professionals, Teh and Yong (2011) found that the sense of selfworth and in-role behavior are related positively to the attitude toward knowledge sharing. In addition, subjective norm and organizational citizenship behavior are related to an intention to share knowledge Bock, Kim, Zmud, and Lee (2005) gathered data from 27 Korean organizations and found that attitudes and subjective norms are related to knowledge sharing. The current study also uses TRA as a theoretical basis, but combines TRA constructs with those of organizational justice for a new perspective. TRA and Organizational Justice theories are described briefly below.

\section{Theory of Reasoned Action}

TRA consists of three general constructs - behavioral intention (BI), attitude (A), and subjective norm (SN) - in which a person's behavioral intention depends on the person's attitude about the behavior and subjective norms $(B I=A+S N)$. According to TRA (Fishbein \& Ajzen, 1975), behavioral intention is a measure of one's intention to perform a specified behavior and represents the primary predictor of actual behavior. Behavioral intentions are defined as a person's decision to perform a particular behavior and represent a summary of the motivation to act: the more the individual intends to do something, the more likely that behavior is to be performed. Attitudes are beliefs about the consequences of performing the behavior and his or her evaluation of these consequences. For example, in the context of knowledge sharing, an individual might think that his or her sharing knowledge with other organizational members is a wise move. Subjective norm is seen as a combination of perceived expectations from relevant individuals or groups along with intentions to comply with these expectations. In other words, "the person's perception that most people who are important to him or her think he should or should not perform the behavior in question" (Fishbein \& Ajzen, 1975). TRA was successfully used to predict behavioral intentions in many domains including information systems. For example, recently, Bulgurcu, Cavusoglu, and Benbasat (2010) used constructs from this theory to investigate information security policy compliance.

\section{Organizational Justice}

Organizational justice refers to the study of fairness within organizational settings and originates from work in social psychology aimed at understanding fairness issues in social interactions (Greenberg \& Colquitt, 2005). Organizational justice encompasses three dimensions: interactive, procedural, and distributive justice (Williams, Pitre, \& Zainuba, 2002). Organizations convey a sense of concern for employee well-being and their contribution to organizational success when rewards and resources are fairly distributed (distributive justice), decision-making procedures are equitable (procedural justice), and supervisors treat employees with dignity and respect (interactive justice) (Rhoades \& Eisenberger, 2002). Loi, Ngo, and Foley (2006) demonstrated that procedural and distributive justice led to increased employee commitment to the organization and intentions to remain. Procedural and interactive (reciprocal) but not distributive justice were found to be significant predictors of software piracy (Douglas, Cronan, \& Behel, 2007; Norazah, Ramayah, \& Norbayah, 2011).

The fairness assessment contributes to the understanding a wide range of human attitudes and behavior in organizations: performance evaluations (Beehr, Nair, Gudanowski, \& Such, 2004), selection of benefit plans (Cole \& Flint, 2004), and, most importantly, decision making (Tatum, Eberlin, Kottraba, \& Bradberry, 2003). The fairness heuristic (Lind, Kulik, Ambrose, \& de Vera 
Park, 1993) states that perceptions of fairness in one area influence perceptions of fairness in another area. Moreover, justice perceptions impact attitudes, behavior, and decisions across a wide variety of social contexts and play an essential role in determining an employee's reaction to organizational outcomes and organizational procedures and the decision making processes (Lind et al., 1993). Employees who perceive overall organizational justice tend to exhibit cooperative behavior (Podsakoff, MacKenzie, Paine, \& Bachrach, 2000). Since knowledge sharing is discretionary in nature and cannot be forced, cooperation on behalf of employees is critical. However, individual perceptions of their value to the organization are based largely on their expertise, tacit knowledge combined with a certain set of unique skills that they possess. When knowledge is shared, the individual may perceive loss of expert power. In order to alleviate the fear of losing one's value to the organization in terms of expertise, management needs to ensure that all components of organizational justice have been implemented (Park et al., 2009).

\section{Research Framework and Hypotheses Development}

Figure 1 depicts the research model. It combines aspects of TRA with Organizational Justice to improve understanding of individual motivations to share knowledge. Hypothesis 1 stems from TRA. Hypotheses 2-3 concern the influence of organizational justice constructs on the intention to share knowledge and attitude.

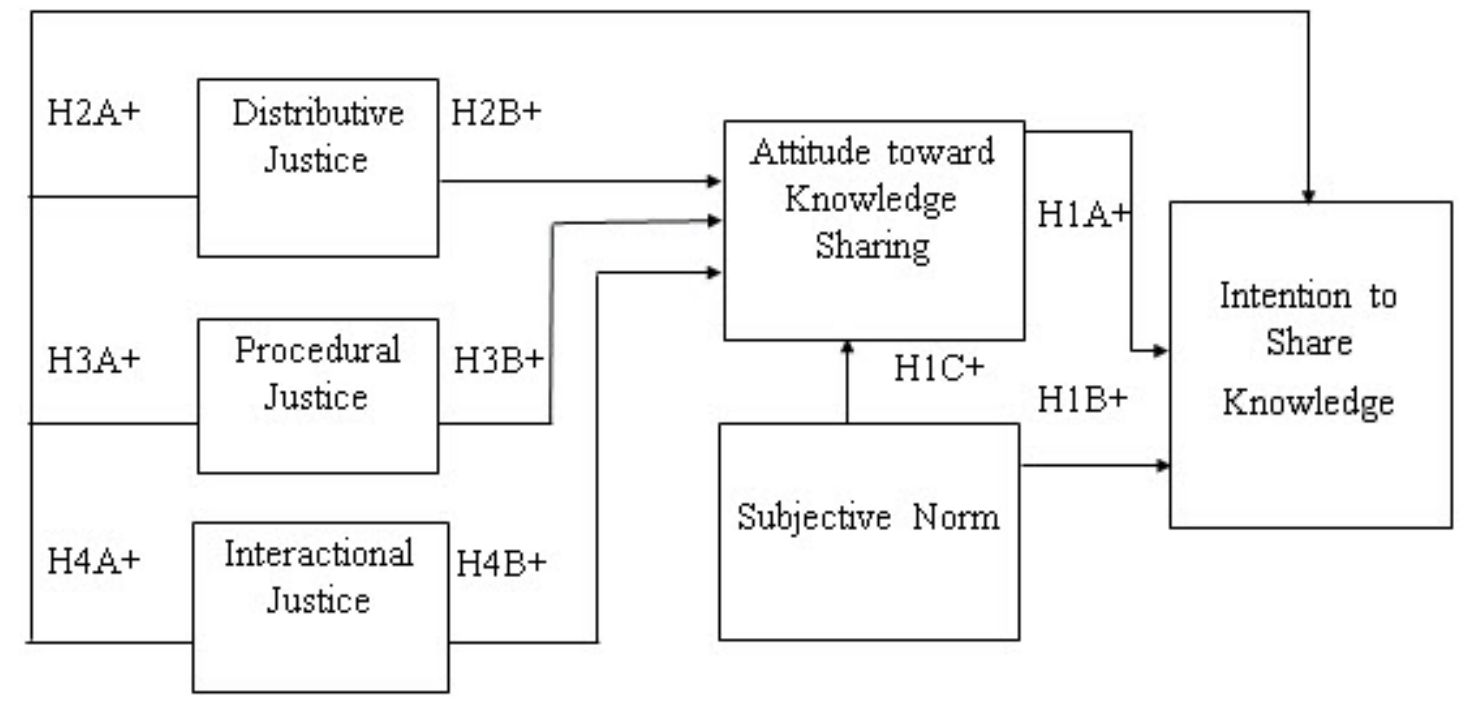

Figure 1: Hypothesized

research model

TRA (Ajzen \& Fishbein, 1980) states that attitudes and subjective norms are the major determinants of a person's intention. Attitudes toward a behavior (such as knowledge sharing) are based on behavioral beliefs about the expected consequences of a specified behavior and the favorable or unfavorable evaluation of these consequences. Higher attitudinal disposition towards knowledge sharing was shown to increase knowledge sharing intention (Bock et al., 2005).If knowledge outcomes of work belong to the organization and if employees are happy within their organization, they are more willing to share their expertise for the benefit of the organization (Constant, Kiesler, \& Sproull, 1994). Thus, organizational commitment and beliefs in the organizational ownership of work outcomes encourage knowledge-sharing attitudes. Moreover, knowledge sharing often leads to an increase in self-esteem that is based on a sense of competence, power, and 
achievement (Constant et al., 1994). Hence, people who have positive feelings about sharing their knowledge are more inclined to engage in sharing this knowledge.

H1A: The more favorable the attitude toward knowledge sharing, the greater the intention to share knowledge.

According to TRA, the subjective norm looks at the influence of people in one's social environment on his/her behavioral intentions. This is formed from normative beliefs, which refers to the individual's beliefs that important relevant others expect him/her to engage in the behavior of interest, in this case knowledge sharing. These beliefs are weighted by the importance that the individual places on each of the relevant others' opinions. In the organizational context, these relevant others include management and peer groups. Management has control over employee compensation policies, performance appraisal, and career advancement. Management can promote knowledge management initiatives. Thus, employees would want to comply with the management expectations of engaging in knowledge sharing behavior. Similarly, peer group acceptance has an important effect on one's professional experience. Previously published research has shown subjective norm to be an important antecedent to behavioral intention (Bock et al., 2005; Teh \& Yong, 2011). Thus, it is proposed that employee's normative beliefs about the management and peer group expectations have a positive effect on his/her intention to share knowledge.

\section{H1B: The greater the subjective norm to share knowledge, the greater the intention to share knowledge.}

Organizations whose internal environments are most effective at creating and integrating new knowledge into the organization have norms and practices that demand broad participation in knowledge gathering and distributing information about the external environment. This level of collaboration is possible only when a high degree of affiliation is achieved that in turn requires presence of organizational justice perceived by all the members of the organization. Norms and practices must go beyond encouraging debate and dialogue to facilitating contributions from individuals at multiple levels of the organization. Subjective norm refers to a person's perception that important others desire the performance of a specific behavior. In most instances, people hold favorable attitudes toward behaviors their important others think they should perform (Ajzen \& Fishbein, 1980). Hence, an individual's attitudes toward knowledge sharing are molded by their peers.

\section{H1C: The greater the subjective norm to share knowledge, the more favorable the attitude toward knowledge sharing.}

Distributive justice refers to the fairness of outcomes received. When compared to procedural and interactional types of justice, distributive justice correlates more with reactions to specific outcomes rather than reactions to the organization (Folger \& Cropanzano, 1998). By extending the distributive justice perspective to knowledge sharing, the individuals' perceptions of the input/output ratio in the exchange process will influence their intention to share their knowledge. Distributive justice requires that an individual's inputs to the "common good" be rewarded adequately with outcomes. In a social exchange process, extrinsic rewards play an important role. Obtaining tangible reward, like money for contributing knowledge (He \& Wei, 2009) can become an important extrinsic motivator that is crucial for knowledge transfer (Osterloh \& Frey, 2000). In addition, if parties in the knowledge-sharing process perceive that it is a mutually beneficial relationship, they are more inclined to share their knowledge with another party.

\section{H2A: The greater the perceived distributive justice, the greater the intention to share knowledge.}

Anticipated extrinsic rewards hinder creation of positive attitudes toward knowledge sharing. This surprise finding is potentially attributed to differences between management's and employees' perception of the appropriate extrinsic rewards (Bock et al., 2005). Paying close attention to 
fairness in group reward distribution such that rewards are proportional to individual's contributions can help alleviate such discrepancies (Cropanzano, Prehar \& Chen, 2002). However, how one's "contributions" are defined can be ambiguous because a number of possible equity rules exist, such as past performance, tenure within an organization, or rank.

One comprehensive study of equity, equality, and need rules (Conlon, Porter, McLean, \& Parks, 2004) found that past performance (equity) and random draw (equality) rules were seen as more fair and likely to lead to less intragroup conflict than other fairness standards (such as future performance, personal need, or rank). However, these results were often mitigated by other factors, such as what was being allocated (money versus goods) and whether the respondent benefited or was harmed by the decision (Conlon et al., 2004).

\section{$H 2 B$ : The greater the perceived distributive justice, the more favorable the attitude toward knowledge sharing.}

Procedural justice refers to an exchange between an organization and its employees. Procedural justice has to do with following procedures that are consistent, unbiased, accurate, correctable, representative, and ethical (Robinson, Moye, \& Locke, 1999). Although employees' reactions toward an organization were studied extensively (Folger \& Cropanzano, 1998) relatively little is known about how procedural justice might affect employees' intention to share their knowledge.

The process by which incentives are awarded has a role in this, for example, if everyone in the team gets equal rewards, regardless of their individual contributions, then free-riding may be encouraged and top performers might be discouraged from doing their best. However, if the individual contributions to the group (team, unit) performance are evaluated appropriately and rewarded, then individuals are more inclined to share their expertise and knowledge.

H3A: The greater the perceived procedural justice, the greater the intention to share knowledge.

Research on procedural justice has demonstrated that the fairness of procedures and treatment are important sources of employee attitudes and behavior (Lind et al., 1993). If the organizational policies and procedures are perceived as fair and equitable, organizational citizenship behavior will be enhanced (Tepper \& Taylor, 2003) and employees are more likely to have positive attitudes towards sharing their expertise. Regardless of how the rewards are distributed, perceptions of bias in the evaluation process will lead to decrease in the procedural justice perceptions; hence, the absence of bias can lead to positive knowledge sharing attitudes.

\section{$H 3 B$ : The greater the perceived procedural justice, the more favorable the attitude toward knowledge sharing.}

Although pay is important, in employment relationships employees increasingly expect more than just wages in return for fair work. It is important to recognize the value of social bonding and informal networks in facilitating knowledge sharing initiatives. Relationships among people in organizations play a significant role in the creation of and transfer of knowledge. For example, the psychological contract view (Rousseau, 1990) holds that individuals have certain beliefs about mutual obligations in relationships and, as a result, in employment situations expect not only tangible but also intangible rewards, like reputation. Previous studies have shown that building a reputation is a strong motivator for knowledge-sharing (Kankanhalli, Tan, \& Wei, 2005). Individuals participate in knowledge sharing to improve or establish a reputation or to earn peer recognition (Wasko \& Faraj, 2005).

H4A: The greater the perceived interactional justice, the greater the intention to share knowledge.

Reciprocity is a form of conditional gain, meaning that people expect future benefits from their present actions. People reciprocate previous friendly actions (Fehr \& Gachter, 2000), which they 
believe are likely to lead to mutual benefits (Hsu \& Lin, 2008) or knowledge feedback in the future (Kankanhalli et al., 2005) and thus they have stronger knowledge-sharing intentions (Lin 2007). Bock et al. (2005) included Anticipated Reciprocal Relationships as an important determinant of attitude towards knowledge sharing. This construct can be viewed through the lens of the interactional justice. Items such as "My knowledge sharing would draw smooth cooperation from outstanding members in the future" from Bock et al. (2005) also indicate that employees expect reciprocity when sharing their knowledge, further reflecting employee beliefs that knowledge sharing will lead to the improvement of their relationships with others. Both of these inferences are supported by interactional justice. If individuals treat each other with dignity and respect, a sense of mutual trust and openness will promote knowledge sharing behavior.

\section{H4B: The greater the perceived interactional justice, the more favorable the attitude toward knowledge sharing.}

\section{Methodology}

To validate the model, a survey instrument was created based upon existing theory, and, after pilot testing, data were collected using the final survey instrument. All measures were contextualized to this research from those developed and validated by others, thus supporting the validity of these constructs, which was further enhanced by subjecting the instrument to a series of development steps. Table A-1 in the Appendix shows the definition of each construct used in the study, its source, and the reported reliability in the original study.

All items were scored on a five-point Likert scale anchored by two possibilities: (1) very rarely to very frequently and (2) strongly disagree to strongly agree. The items measuring each construct are listed in the Appendix Table A-2. As with the subjective norm scale used by Bock et al. (2005), subjective norm is the sum of normative beliefs (NB), which are the individual's belief that important relevant others expect him/her to engage in behavior of interest, multiplied by the individual's motivation to comply (MC). Thus, it is expressed mathematically as:<smiles>CC(C)(C)[Mg]</smiles>

The survey and each construct's corresponding items were reviewed for content validity by the research team that included three faculty members with considerable expertise in survey instrument development. Appropriate modifications were made after that initial review and subsequently a team of doctoral students who were trained in research and survey methodologies were asked to provide an additional review. Their input was evaluated by the research team and all relevant and needed changes were incorporated into the instrument. Upon completion of all modifications a pilot study was conducted. Participants in the pilot study were IT professionals who were working toward earning advanced degrees at a university in the southwestern part of the United States and advisory board members of the university IT department. After incorporating suggestions of academicians and practitioners, the final survey was administered.

The research population for the full study consisted of IT professionals across a broad spectrum in terms of organizational size, tenure, and industry classifications in the United States. The survey was mailed to 4000 IT professionals with names and addresses purchased from a market research company database. The survey yielded 220 usable responses for a response rate of 5.5\%, which is a limitation of the study. Other published surveys, however, have had a similar response rate (Pflughoeft, Ramamurthy, Soofi, Yasai-Ardekani, \& Zahedi, 2003).There can be several reasons for the low response rate in the current study. First, the length of the instrument might have dissuaded responses. Second, the nature of the survey dealt with a sensitive subject - the degree 
to which individuals felt as if they had been dealt with justly in their organization. Because the survey came from an unsolicited and potentially unknown source, even though anonymity was stressed in the cover letter, respondents may have been reticent to reply.

The study was conducted in the United States and it is possible that its findings may not be transferable to other countries, due to cultural differences. Various cultural dimensions have been explored by numerous researchers, with the work of Hofstede (2001) being most familiar. In his work, Hofstede (2001) classifies cultures along five different dimensions: individualism, power distance, masculinity, uncertainty avoidance index, and long-term orientation. Each of these dimensions can affect individual behaviors and will influence how individuals share knowledge in an organizational setting. For instance, Americans are quintessentially individualistic, whereas Asian cultures are typically collectivist in orientation, so this tendency to place personal goals over those of the organization may produce different results in a knowledge sharing scenario in US versus China or Japan.

An important step in instrument validation is to test the instrument for reliability to ensure measurement accuracy that is to minimize the measurement error. Reliability refers to the state when a scale yields consistent measures over time (Straub, 1989). Internal consistency tends to be a frequently used type of reliability in the IS domain. It is generally agreed that internal composite reliability should be 0.70 or greater (Hair, Anderson, Tatham, \& Black, 1998).Table A-3 in the Appendix shows that in this study, all were above 0.85 , therefore demonstrating adequate reliability.

In order to claim the validity of an instrument it is necessary to have both convergent and discriminant validity (Bagozzi \& Fornell, 1989). Convergent validity ensures that all items measure a single underlying construct (Fornell \& Larcker, 1981). As a minimum threshold of convergent validity, the average variance extracted (AVE) by the items associated with a given construct should be greater than 0.50 , indicating that more than half of the variance is the true score, not error (Fornell \& Larcker, 1981). AVE can be calculated by the following equation (Hair et al., 1998):

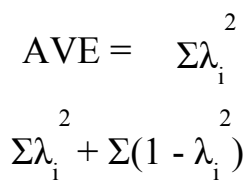

$\lambda i$ represents the factor loading for a particular item that measures a construct. An examination of the AVE for each construct (in Table A-4) reveals that all construct AVE scores are above 0.50 and support adequate convergent validity.

Discriminant validity reflects the extent to which measures for each construct are distinctly different from each other (Straub, 1989). As a rule, the most rigorous method for testing discriminant validity involves AVE estimates for each latent variable and the square of the correlations among the latent variables. According to this method, the AVE should be greater than the square of the correlation between construct pairs (Fornell \& Larcker, 1981). Table A-3 in the Appendix contains the construct correlations and on the diagonal the square root of AVE. It is clear that all between-construct correlations are smaller than the square root of the AVE for each construct and its measures, indicating that discriminant validity has been demonstrated.

To further support convergent and discriminant validity, confirmatory factor analysis (CFA) was performed. In CFA, the pattern of loadings of the measurement items on the latent constructs is specified. Then, the fit of this pre-specified model is analyzed by looking at the pattern of loadings of the measurement items and comparing it to the theoretically anticipated factors. When the 
measurement items load more highly on their theoretically assigned factor and not others then convergent and discriminant validity is demonstrated. The results of examining the present data support convergent and discriminant validity (see Appendix Table A-5).

Non-response bias is an important source of bias in survey research. When present, it can lead to conclusions that differ systematically from the actual situation in the population (Kerlinger \& Lee, 2000). Non-response bias was assessed by comparing the early and late respondents (De Winter \& Dodou, 2012). Independent t-tests were performed on early and late response groups to assess whether they differ in terms of industry type, organizational tenure, and job/position type. The results indicated no significant differences between the two groups at the .05 significance level.

To detect possible common method variance (CMV), Harman's single-factor test was performed in the exploratory factor analysis on all items in the model (Podsakoff, MacKenzie, Lee, \& Podsakoff, 2003). The unrotated solution revealed that more than one factor was extracted and none of the factors explained an overwhelming portion of the variance. Therefore, CMV was not a concern.

\section{Results}

LISREL was used to test the conceptual research model of this study because our model is grounded on existing theory and data collection was done using validated scales. A sample size of 150 or more is recommended (Anderson \& Gerbing, 1988). The sample size for our study was 220 and was, therefore, deemed acceptable. All responses exhibited good univariate normality with all distributions indicating skewness less than 1.2 and kurtosis less than 1.2 in absolute value (see Table A-6 in the Appendix). These values are well within the robustness thresholds for normality (skewness of 2 and kurtosis of 7) established for maximum-likelihood estimation through Monte Carlo studies (Curran, West, \& Finch, 1996).

Fit statistics indicate good fit of the research model to the data. The Root Mean Squared Error of Approximation (RMSEA) value is0.067. A value below 0.080 is considered a good fit (MacCallum, Browne, Sugawara, 1996). RMSEA shows how well the model fits the population's covariance matrix and is regarded as one of the most important fit indices (Diamantopoulos \& Siguaw, 2000). The values of the Normed Fit Index (NFI) and Non-Normed Fit Index (NNFI) are 0.93 and 0.95 , respectively. The closer these indices are to 1.0 , the better the fit. They both indicate a close-fitting model. The value of the Comparative Fit Index (CFI) of 0.96 also indicates a close fit between the model and the data. Therefore, the totality of the model fit appears to be good.

Figure 2 shows the estimate weight for each arrow connecting a latent construct with a corresponding latent construct it is hypothesized to effect. The results of the hypotheses testing are shown below in Table 1. 


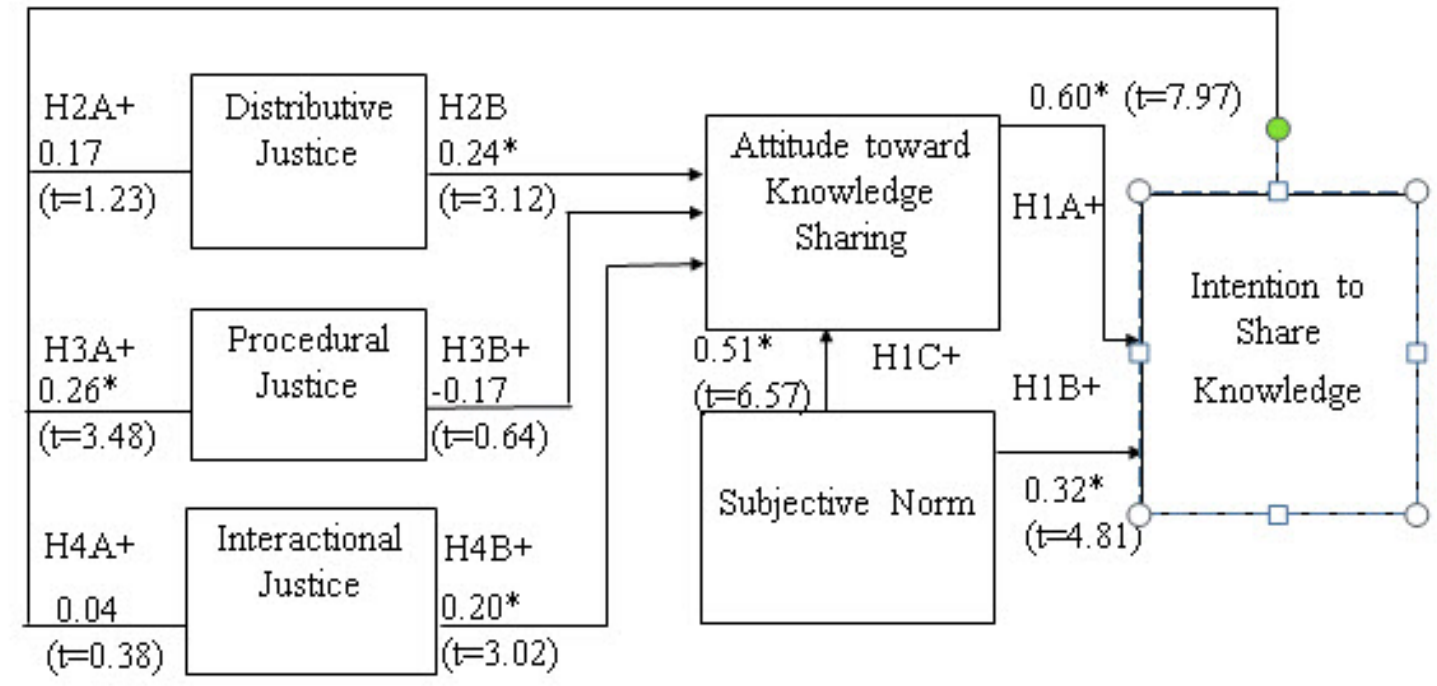

Figure 2: Final model

Note: The model shows path coefficients and corresponding t-wabue in parertheses.

"Significant at $\mathrm{p}<0.05$ 


\begin{tabular}{|c|c|c|c|}
\hline \multicolumn{4}{|c|}{ Table 1: Results of the hypotheses testing } \\
\hline Hypothesis & Hypothesis Statement & Results & t-values \\
\hline H1A & $\begin{array}{l}\text { The more favorable the attitude toward knowledge shar- } \\
\text { ing, the greater the intention to share knowledge. }\end{array}$ & Supported & 7.97 \\
\hline H1B & $\begin{array}{l}\text { The greater the subjective norm to share knowledge, the } \\
\text { greater the intention to share knowledge. }\end{array}$ & Supported & 4.81 \\
\hline $\mathrm{H} 1 \mathrm{C}$ & $\begin{array}{l}\text { The greater the subjective norm to share knowledge, the } \\
\text { more favorable the attitude toward knowledge sharing. }\end{array}$ & Supported & 6.57 \\
\hline $\mathrm{H} 2 \mathrm{~A}$ & $\begin{array}{l}\text { The greater the perceived distributive justice, the greater } \\
\text { the intention to share knowledge. }\end{array}$ & Not Supported & 1.23 \\
\hline $\mathrm{H} 2 \mathrm{~B}$ & $\begin{array}{l}\text { The greater the perceived distributive justice, the more } \\
\text { favorable the attitude toward knowledge sharing. }\end{array}$ & Supported & 3.12 \\
\hline $\mathrm{H} 3 \mathrm{~A}$ & $\begin{array}{l}\text { The greater the perceived procedural justice, the greater } \\
\text { the intention to share knowledge. }\end{array}$ & Supported & 3.48 \\
\hline H3B & $\begin{array}{l}\text { The greater the perceived procedural justice, the more } \\
\text { favorable the attitude toward knowledge sharing. }\end{array}$ & Not Supported & 0.64 \\
\hline $\mathrm{H} 4 \mathrm{~A}$ & $\begin{array}{l}\text { The greater the perceived interactional justice, the greater } \\
\text { the intention to share knowledge. }\end{array}$ & Not Supported & 0.38 \\
\hline H4B & $\begin{array}{l}\text { The greater the perceived interactional justice, the more } \\
\text { favorable the attitude toward knowledge sharing. }\end{array}$ & Supported & 3.02 \\
\hline
\end{tabular}

\section{Discussion}

All the hypotheses examining the relationship between attitude toward knowledge sharing, subjective norm, and the intention to share knowledge were strongly supported. TRA (Ajzen \& Fishbein, 1980) states that attitudes and subjective norms are the major determinants of a person's intention. Subjective norm refers to the social pressure or an individual's perception of what referent others expect of him/her multiplied by a person's motivation to comply. Believing that knowledge sharing is a socially expected workplace behavior increases sharing behavior Attitude toward knowledge sharing and subjective norm were, as expected, significant predictors of intention to share knowledge.

Testing of organizational justice elements on the attitude and intention to share knowledge produced mixed results. Research suggests that justice perceptions are conceptualized along three dimensions: the fairness of outcome distributions (distributive justice); the fairness of procedures used to determine outcome distributions (procedural justice), and the quality of interpersonal treatment received when procedures are implemented (interpersonal justice). 
Procedural justice refers to following proper methods in an exchange between an organization and its employees. The data in the present study show that procedural justice affects knowledge sharing intention. The more someone considers a process to be fair, the more tolerant that person is about the consequences of the process. In terms of knowledge sharing, this could mean that if an individual believes that the process to evaluate knowledge sharing is included fairly in the performance appraisal process, then that individual is more likely to engage in knowledge sharing.

Distributive justice refers to the fairness of outcomes received. The results show that while distributive justice does not directly affect knowledge sharing intention, it does so through attitude. An equitable distribution requires calculation of the proportion of resources that recipients deserve on the basis of their relative contributions to the group. The willingness of people to share knowledge will depend on their attitude toward knowledge sharing as a result of the perceptions of costs (tangible or intangible) involved.

Like distributive justice, the data show that while interactional justice does not directly affect knowledge sharing it is mediated by attitude. Knowledge sharing, by definition, falls under the category of cooperation. Since attitudes are beliefs about the consequences of performing the behavior (knowledge sharing) and his or her evaluation of these consequences, the parties to an exchange must believe that they will benefit from the relationship. That is, that they must believe that knowledge sharing is a 'win-win' scenario for everyone involved. Hence, people are more likely to share knowledge with those who share it in return. Moreover, when an individual perceives that the majority of exchanges among members in an organization are based on mutual respect and consideration of others' feelings (interactional justice), the environment is perceived as fair and just, and people are more likely to contribute to the organization (Staley, Dastoor, Magner, \& Stolp, 2003).

The findings show the three constructs of justice influence knowledge sharing intention. The model fit also shows that Attitude toward Knowledge Sharing fully mediates Distributive Justice and Interactional Justice but does not mediate Procedural Justice. This finding suggests that the constructs of justice have distinct differences in how the individual responds and, as such, this finding has implications for future research. In summary, attitude and subjective norm are directly related to knowledge sharing intention. Procedural justice is also directly related, however, the distributive and interactional justice is mediated through attitude.

\section{Implications}

Our study contributes to the informing science transdiscipline. According to Cohen (2009), informing takes place in a complex environment. Our data show that informing in a firm is affected by the organizational practices adopted. Specifically, we explore the importance of norms and attitudes that affect the complex environment in which knowledge sharing occurs. Our findings reveal that all three components of organizational justice - procedural, distributive, and interactional - are related directly or indirectly to knowledge sharing intention. If employees perceive organizational environment to be fair and just, then individuals' are more likely to share knowledge. Employees see procedures as fair to the extent that these procedures show respect for employees as valued members of their organization.

Our results reaffirm that the informer and the information transmission components in the Informing Science framework matters, since the perceptions of organizational justice significantly influences the degree of knowledge sharing. Managers can stress the importance of knowledge sharing to the success of the organization by establishing organizational policies conducive to knowledge sharing among organizational members. For example, managers can set up reward structures for recognizing individuals willing to share their knowledge and expertise with others. It is critical that these policies be implemented consistently across the organization. 
Ibragimova, Ryan, Windsor, \& Prybutok

A key contribution of this study is the development of a model that combines two theoretically sound theories and tests them in the knowledge sharing context. Thus, we have developed an integrated model that support the informing science framework and should, therefore, be broadly applicable. Since both the informer and the client are influenced by human-related issues, they are best examined by those fields of study that deal with understanding cognitive, behavioral, and social issues (Cohen, 2009). Our data demonstrate that the informer is impacted by his or her own psychological "fragilities" in terms of attitudes and the social influences of others. The informing environment influences the informer in terms of perceptions of organizational practices regarding justice.

\section{Limitations and Future Research}

This study has some limitations that potentially affect the ability to generalize the findings. Our moderate response rate could affect the external validity of the finding in this study. Also, in any survey there is the possibility of sampling error. Sampling errors occur due to difficulties in gaining access to potential respondents that make the sample representative of the target population (Braverman, 1996). Nevertheless, we believe this is unlikely because the results of this study are consistent with the findings of Bock et al. (2005) in terms of TRA constructs. While our study provides a strong theoretical basis and preliminary empirical results upon which future research can build, additional research related to the organizational justice constructs is encouraged. For example, an emerging concept of informational justice can be added to the model. Also, all of the organizational justice constructs can be explored as part of a second-order factor of organizational climate. In addition, case study methods may provide more context-rich results. An important area for future work is to conceptualize and test how various constructs in the model are mediated by other individual characteristics that were not measured in this initial study, such as propensity to trust.

\section{Conclusion}

Determining how organizational justice influences the sharing of knowledge among individuals within organizations constitutes an important area of research. Park et al. (2009) examined the justice constructs but in a less complex model that did not include attitude and subjective norm from TRA. Such complexity is consistent with moving research findings further toward application because of the transdisciplinary nature of the informing environment in which knowledge is shared. The findings in this study show that distributive and interactional justice are mediated by attitude and therefore shows the complexity of the relationship between the informer and the informing environment. Cohen's (1999; 2009) description of the Informing Science framework in-

cludes the contextual environment of the informer, information transmission and receiving media, and client. The findings in this work contribute to the transdiscipline of the informing sciences because they highlight the importance of organization justice constructs toward influencing knowledge sharing and as such shaping the informing environment. The model explores knowledge sharing (a form of informing) through the lens of TRA and organizational justice theory.

The model shows how the three constructs of justice influence the willingness to share knowledge. Such a finding has implications across a wide set of disciplines and applications and further supports the transdisciplinary nature of this study. In addition, the model shows that Attitude toward Knowledge Sharing fully mediates Distributive Justice and Interactional Justice but does not mediate Procedural Justice. As such, our findings suggest that shaping attitudes may potentially lead to influencing knowledge sharing. 


\section{References}

Ajzen, I., \& Fishbein, M. (1973). Attitudinal and normative variables as predictors of specific behaviors. Journal of Personality and Social Psychology, 27, 41-57.

Ajzen, I., \& Fishbein, M. (1980). Understanding attitudes and predicting social behavior, Englewood Cliffs: Prentice Hall.

Anderson, J. C., \& Gerbing, D. W. (1988). Structural equation modeling in practice: A review and recommended two-step approach. Psychological Bulletin, 103(3), 411-423.

Bagozzi, R. P., \& Fornell, C. (1989). Consistency criteria and unidimensionality: An attempt at clarification. Advances in Consumer Research, 16(1), 321-325.

Bock, G. W., Zmud, R. W., Kim, Y. G., \& Lee, J. N. (2005). Behavioral intention formation in knowledge sharing: Examining the roles of extrinsic motivators, social psychological forces and organizational climate. MIS Quarterly, 29(1), 87-111.

Boland, R. J. (1987).The in-formation of information systems. In R. J. Boland \& R. A. Hirscheirm (Eds), Critical issues in information systems (pp. 363-379). New York, NY: John Wiley \& Sons.

Beehr, T. A., Nair, V. N., Gudanowski, D. M., \& Such, M. (2004). Perceptions of reasons for promotion of self and others. Human Relations, 57(4), 413-438.

Braverman, M. T. (1996). Sources of survey error: Implications for evaluation studies. In M T. Braverman \& J. K. Slater (Eds.), Advances in survey research (pp. 17-28). San Francisco, CA: Jossey-Bass Publishers.

Bulgurcu, B., Cavusoglu, H., \& Benbasat, I. (2010). Information security policy compliance: An empirical study of rationality-based beliefs and information security awareness. MIS Quarterly, 34(3), 523-A7.

Chiu, C., Hsu, M., \& Wang, E. T. G. (2006). Understanding knowledge sharing in virtual communities: An integration of social capital and social cognitive theories. Decision Support Systems, 42(3), 1872-1888.

Cho, N., Li, G., \& Su, C. (2007). An empirical study on the effect of individual factors on knowledge sharing by knowledge type. Journal of Global Business \& Technology, 3(2), 1-15.

Cohen, E. B. (1999). From ugly duckling to swan: Reconceptualizing information systems as a field of the discipline informing science. Journal of Computing and Information Technology, 7(3), 213-219.

Cohen, E. B. (2009). A philosophy of informing science. Informing Science: the International Journal of an Emerging Transdiscipline, 12, 1-15. Retrieved from http://www.inform.nu/Articles/Vol12/ISJv12p001-015Cohen399.pdf

Cole, N. D., \& Flint, D. H. (2004). Perceptions of distributive and procedural justice in employee benefits: flexible versus traditional benefit plans. Journal of Managerial Psychology 19(1), 19-40.

Conlon, D. E., Porter, C. O., McLean, L. H., \& Parks, J. (2004). The fairness of decision rules. Journal of Management, 30(3), 329-349.

Constant, D., Kiesler, S., \& Sproull, L. (1994). What's mine is ours, or is it? A study of attitudes about information sharing. Information Systems Research, 5(4), 400-421.

Cropanzano, R., Prehar, C. A., \& Chen, P. Y. (2002).Using social exchange theory to distinguish procedural from interactional justice. Group and Organization Management, 27(3), 324-351.

Curran, P. J., West, S. G., \& Finch, J. F. (1996).The robustness of test statistics to nonnormality and specification error in confirmatory factor analysis. Psychological Methods, 1(1), 16-29.

De Winter, J., \& Dodou, D. (2012). Factor recovery by principal axis factoring and maximum likelihood factor analysis as a function of factor pattern and sample size. Journal of Applied Statistics, 39(4), 695710 .

Diamantopoulos, A., \& Siguaw, J. A. (2000). Introducing LISREL. London: Sage Publications. 
Douglas, D. E., Cronan, T. P., \& Behel, J. D. (2007). Equity perceptions as a deterrent to software piracy behavior. Information \& Management, 44(5), 503-512.

Fehr, E., \& Gachter, S. (2000). Fairness and retaliation: The economics of reciprocity. Journal of Economic Perspectives, 14(3), 159-181.

Fishbein, M., \& Ajzen, I. (1975). Belief attitude, intention, and behavior: An introduction to theory and research. London: Addison-Wesley.

Folger, R., \& Cropanzano, R. (1998). Organizational justice and staffing decisions: On the horns of the justice dilemma? In R. Folger \& R. Cropanzano, Organizational justice and human resource management (pp. 81-107), Thousand Oaks, CA: Sage.

Fornell, C., \& Larcker, D. F. (1981). Evaluating structural equation models with unobservable variables and measurement error. Journal of Marketing Research, 18, 39-50.

Gackowski, Z. J. (2012). The helix of human cognition: Knowledge management according to DIKW, E2E, and the proposed view. Informing Science: the International Journal of an Emerging Transdiscipline, 15, 93-119.

Garud, R., \& Kumaraswamy, A. (2005). Vicious and virtuous circles in the management of knowledge: The case of Infosys Technologies. MIS Quarterly, 29(1), 9-33.

Greenberg, J., \& Colquitt, J. A. (2005). The handbook of organizational justice. Mahwah, NJ: Lawrence Erlbaum Associates.

Hair, J. F., Anderson, R. E., Tatham, R. L., \& Black, W. C. (1998). Multivariate data analysis (5th ed.). Upper Saddle River, NJ: Prentice Hall.

He, W., \& Wei, K. K. (2009). What drives continued knowledge sharing? An investigation of knowledge contribution and -seeking beliefs. Decision Support Systems, 46(4), 826-838.

Hofstede, G. (2001). Culture's consequences. Thousand Oaks, CA: Sage Publications.

Hsu, C. L., \& Lin, J. C. C. (2008). Acceptance of blog usage: The roles of technology acceptance, social influence and knowledge sharing motivation. Information \& Management, 45(1), 65-74.

Jean-Paul, P., \& Shih, C. (2011). An empirical study on the combined effects of KM enablers and KM strategies organizational performance: A case study of Taiwan ICDF. Review of Management Innovation \& Creativity, 4(10), 1-22.

Kankanhalli, A., Tan, B. C. Y., \& Wei, K. K. (2005). Contributing knowledge to electronic knowledge repositories: an empirical investigation. MIS Quarterly, 29(1), 113-143.

Kerlinger, F. N., \& Lee, H. B. (2000). Foundations of behavioral research (4th ed.). New York: Thomson Learning.

Lin, H. (2007). Effects of extrinsic and intrinsic motivation on employee knowledge sharing behavior. Journal of Information Science, 33(2) 135-149.

Lind, E. A., Kulik, C.T., Ambrose, M., \& de Vera Park, M. V. (1993). Individual and corporate dispute resolution: Using procedural fairness as a decision heuristic. Administrative Science Quarterly, 38, 224-248.

Loi, R., Ngo H., \& Foley, S. (2006). Linking employees' justice perceptions to organizational commitment and intention to leave: The mediating role of perceived organizational support. Journal of Occupational \& Organizational Psychology, 79(1), 101-120.

MacCallum, R. C., Browne, M. W., \& Sugawara, H. M. (1996). Power analysis and determination of sample size for covariance structure modeling. Psychological Methods, 1(2), 130-149.

Moorman, R. H. (1991). Relationship between organizational justice and organizational citizenship behavior: do fairness perceptions influence employee citizenship? Journal of Applied Psychology, 76, 845855. 
Niehoff, B. P., \& Moorman, R. H. (1993). Justice as a mediator of the relationship between methods of monitoring and organizational citizenship behavior. Academy of Management Journal, 36, 527-556.

Norazah, M. S., Ramayah, T., \& Norbayah M. S. (2011). Understanding consumer intention with respect to purchase and use of pirated software. Information Management \& Computer Security, 19(3), 195-210.

Osterloh, M., \& Frey, B. S. (2000). Motivation, knowledge transfer, and organizational forms. Organization Science, 11(5), 538-550.

Park, H., Son, S. Y. Lee, S., \& Yun, S. (2009). Organizational justice and knowledge sharing. International Journal of Business Research, 9(4), 180-185.

Pflughoeft, K. A., Ramamurthy, K., Soofi, E. S., Yasai-Ardekani, M., \& Zahedi, F. (2003).Multiple conceptualizations of small business Web use and benefit. Decision Sciences, 34(3), 467-512.

Podsakoff, P. M., MacKenzie, S. B., Paine, J. B., \& Bachrach, D.G. (2000). Organizational citizenship behaviors: A critical review of the theoretical and empirical literature and suggestions for future research. Journal of Management, 26, 513-563.

Podsakoff, P. M., MacKenzie, S. B., Lee, J.-Y., \& Podsakoff, N. P. (2003). Common method biases in behavioral research: A critical review of the literature and recommended remedies. Journal of Applied Psychology, 88, 879-903.

Rhoades, L. \& Eisenberger, R. (2002). Perceived organizational support: A review of the literature. Journal of Applied Psychology, 87(4), 698-714.

Robert, L. P, Dennis, A. R., \& Ahuja, M. K. (2008). Social capital and knowledge integration in digitally enabled teams. Information Systems Research, 19(3), 314-334.

Robinson, Q. M., Moye, N. A., \& Locke, E. A. (1999). Identifying a missing link between participation and satisfaction: The mediating role of procedural justice perceptions. Journal of Applied Psychology, 84, 585-593.

Rousseau, D. M. (1990). New hire perspectives of their own and their employers' obligations: A study of psychological contracts. Journal of Organizational Behavior, 11, 389-400.

Ryan, S. D., Windsor, J. C., Ibragimova, B., \& Prybutok, V. R. (2010). Organizational practices that foster knowledge sharing: Validation across distinct national cultures. Informing Science: the International Journal of an Emerging Transdiscipline, 13, 139-164.

Staley, A. B., Dastoor, B., Magner, N. R., \& Stolp, C. (2003).The contribution of organizational justice in budget decision-making to federal managers' organizational commitment. Journal of Public Budgeting, Accounting and Financial Management, 15(4), 505-524.

Straub, D. W. (1989). Validating instruments in IS research. MIS Quarterly, 13(3), 147-169.

Tatum, B. C., Eberlin, R., Kottraba, C., \& Bradberry, T. (2003). Leadership, decision making, and organizational justice. Management Decision,4l (10), 1006-1016.

Tepper, B. J., \& Taylor, E. C. (2003). Relationships among supervisors' and subordinates' procedural justice perceptions and organizational citizenship behaviors. Academy of Management Journal, 46(1), 97 105.

Teh, P., \& Yong, C. (2011). Knowledge sharing in IS personnel: Organizational behavior's perspective. Journal of Computer Information Systems, 51(4), 11-21.

Wasko, M., \& Faraj, S. (2000). "It is what one does": Why people participate and help others in electronic communities of practice. Journal of Strategic Information Systems, 9(2-3), 155-173.

Williams, S., Pitre, R., \& Zainuba, M. (2002). Justice and organizational citizenship behavior intentions: Fair rewards versus fair treatment. Journal of Social Psychology, 142(1), 33-44. 


\section{Appendix}

\begin{tabular}{|c|c|c|c|}
\hline \multicolumn{4}{|c|}{ Table A-1: Scale sources } \\
\hline Construct & Definition & Citation & $\begin{array}{l}\text { Reported } \\
\text { Reliabilty } \\
(\alpha) \\
\end{array}$ \\
\hline $\begin{array}{l}\text { Attitude toward } \\
\text { Knowledge Sharing }\end{array}$ & $\begin{array}{l}\text { The degree of one's positive } \\
\text { feelings about sharing one's } \\
\text { knowledge. }\end{array}$ & $\begin{array}{l}\text { Fishbein \& Ajzen (1975); } \\
\text { Bock et al. (2005) }\end{array}$ & 0.75 \\
\hline Subjective Norm & $\begin{array}{l}\text { The person's perception that } \\
\text { important others desire the per- } \\
\text { formance of a specific behavior. }\end{array}$ & Bock et al. (2005) & 0.82 \\
\hline $\begin{array}{l}\text { Intention to Share } \\
\text { Knowledge }\end{array}$ & $\begin{array}{l}\text { The belief to which one be- } \\
\text { lieves that one will engage in a } \\
\text { knowledge-sharing act. }\end{array}$ & $\begin{array}{l}\text { Fishbein \& Ajzen (1975); } \\
\text { Constant et al. (1994) }\end{array}$ & 0.85 \\
\hline Procedural Justice & $\begin{array}{l}\text { Following procedures that are } \\
\text { consistent, unbiased, accurate, } \\
\text { correctable, representative and } \\
\text { ethical. }\end{array}$ & Robinson et al. (1999) & 0.86 \\
\hline Distributive Justice & Fairness of outcomes received. & Moorman (1991) & 0.90 \\
\hline Interactional Justice & $\begin{array}{l}\text { Quality of interpersonal treat- } \\
\text { ment. }\end{array}$ & Niehoff \& Moorman (1993) & 0.82 \\
\hline
\end{tabular}




\begin{tabular}{|c|c|c|}
\hline \multicolumn{3}{|r|}{ Table A-2: Survey items } \\
\hline Construct & Identifier & Item \\
\hline \multirow{5}{*}{$\begin{array}{l}\text { Attitude to- } \\
\text { ward Knowl- } \\
\text { edge Sharing }\end{array}$} & AKS1 & My knowledge sharing with other organizational members is good. \\
\hline & AKS2 & My knowledge sharing with other organizational members is harmful. \\
\hline & AKS3 & $\begin{array}{l}\text { My knowledge sharing with other organizational members is an enjoyable experi- } \\
\text { ence. }\end{array}$ \\
\hline & AKS4 & My knowledge sharing with other organizational members is valuable to me. \\
\hline & AKS5 & My knowledge sharing with other organizational members is a wise move. \\
\hline \multirow{3}{*}{$\begin{array}{l}\text { Subjective } \\
\text { Norm - } \\
\text { Normative } \\
\text { Belief }\end{array}$} & SN1(NB) & $\begin{array}{l}\text { My CEO thinks that I should share my knowledge with other members in the or- } \\
\text { ganization. }\end{array}$ \\
\hline & SN2(NB) & $\begin{array}{l}\text { My boss thinks that I should share my knowledge with other members in the or- } \\
\text { ganization. }\end{array}$ \\
\hline & SN3(NB) & $\begin{array}{l}\text { My colleagues think I should share my knowledge with other members in the or- } \\
\text { ganization. }\end{array}$ \\
\hline \multirow{3}{*}{$\begin{array}{l}\text { Subjective } \\
\text { Norm - Mo- } \\
\text { tivation to } \\
\text { Comply }\end{array}$} & SN1(MC) & Generally speaking, I try to follow the CEO’s policy and intention. \\
\hline & SN2(MC) & $\begin{array}{l}\text { Generally speaking, I accept and carry out my boss's decision even though it is } \\
\text { different from mine. }\end{array}$ \\
\hline & $\mathrm{SN} 3(\mathrm{MC})$ & Generally speaking, I respect and put in practice my colleague's decision. \\
\hline \multirow{6}{*}{$\begin{array}{l}\text { Intention to } \\
\text { Share } \\
\text { Knowledge }\end{array}$} & ISK1 & $\begin{array}{l}\text { I will share my work reports and official documents with members of my organiza- } \\
\text { tion more frequently in the future. }\end{array}$ \\
\hline & ISK2 & $\begin{array}{l}\text { I will always provide my manuals, methodologies and models for members of my } \\
\text { organization. }\end{array}$ \\
\hline & ISK3 & $\begin{array}{l}\text { I intend to share any articles from newspapers/magazines/journals that I find useful } \\
\text { and related to our work with members of my organization. }\end{array}$ \\
\hline & ISK4 & $\begin{array}{l}\text { I intend to share my experience or know-how from work with other organizational } \\
\text { members more frequently in the future. }\end{array}$ \\
\hline & ISK5 & $\begin{array}{l}\text { I will always provide my know-where or know-whom at the request of other organ- } \\
\text { izational members. }\end{array}$ \\
\hline & ISK6 & $\begin{array}{l}\text { I will try to share my expertise from my education or training with other organiza- } \\
\text { tional members in a more effective way. }\end{array}$ \\
\hline \multirow{4}{*}{$\begin{array}{l}\text { Distributive } \\
\text { Justice }\end{array}$} & DJ1 & Employees are fairly rewarded considering their workload and responsibilities. \\
\hline & DJ2 & $\begin{array}{l}\text { Employees are fairly rewarded considering their educational background and ex- } \\
\text { perience. }\end{array}$ \\
\hline & DJ3 & Employees are fairly rewarded for the amount of effort they put forth. \\
\hline & DJ4 & Employees are fairly rewarded for the work they have done well. \\
\hline \multirow{5}{*}{$\begin{array}{l}\text { Procedural } \\
\text { Justice }\end{array}$} & PJ1 & Performance evaluation standards are reasonable. \\
\hline & $\mathrm{PJ} 2$ & Fair and just procedures are used to evaluate performance. \\
\hline & $\mathrm{PJ} 3$ & Objectives and expectations are communicated openly. \\
\hline & PJ4 & Supervisors are ethical in their dealings with their subordinates. \\
\hline & PJ5 & Organizational procedures are applied consistently across the board. \\
\hline \multirow{4}{*}{$\begin{array}{l}\text { Interactional } \\
\text { Justice }\end{array}$} & IJ1 & Employees consider each other's viewpoints on business matters. \\
\hline & IJ 2 & Employees are able to suppress personal issues when discussing business matters. \\
\hline & IJ3 & Employees treat each other with consideration and kindness. \\
\hline & IJ4 & Employees deal with each other in a truthful and respectful manner. \\
\hline
\end{tabular}


Table A-3: Scale statistics

\begin{tabular}{|l|r|r|r|r|}
\hline Scale (\# items) & Mean & StdDev & $\begin{array}{l}\text { Composite } \\
\text { Reliability }\end{array}$ & AVE \\
\hline Attitude toward Knowledge Sharing - AKS (5) & 21.74 & 2.44 & 0.852 & 0.534 \\
\hline Subjective Norm- SN (3) & 51.40 & 12.28 & 0.857 & 0.697 \\
\hline Intention to Share Knowledge - ISK (6) & 24.34 & 3.58 & 0.926 & 0.878 \\
\hline Distributive Justice- DJ (4) & 14.19 & 3.36 & 0.926 & 0.769 \\
\hline Procedural Justice - PJ (5) & 17.36 & 4.12 & 0.906 & 0.682 \\
\hline Interactional Justice- IJ (4) & 14.48 & 2.63 & 0.874 & 0.648 \\
\hline
\end{tabular}

Table A-4: Latent variable correlation matrix with square root of AVE on the diagonal

\begin{tabular}{|c|c|c|c|c|c|c|}
\hline & DJ & ISK & AKS & SN & PJ & IJ \\
\hline DJ & 0.870 & & & & & \\
\hline ISK & 0.245 & 0.929 & & & & \\
\hline AKS & 0.254 & 0.559 & 0.733 & & & \\
\hline SN & 0.252 & 0.483 & 0.458 & 0.817 & & \\
\hline PJ & 0.665 & 0.098 & 0.191 & 0.207 & 0.811 & \\
\hline IJ & 0.570 & 0.189 & 0.359 & 0.170 & 0.448 & 0.796 \\
\hline
\end{tabular}




\begin{tabular}{|l|l|l|l|l|l|l|}
\hline \multicolumn{7}{|c}{ Table A5: Confirmatory Factor Analysis } \\
\hline & DJ & ISK & AKS & SN & PJ & IJ \\
\hline AKS1 & 0.175 & 0.325 & 0.697 & 0.287 & 0.095 & 0.242 \\
\hline AKS2 & 0.149 & 0.267 & 0.497 & 0.293 & 0.165 & 0.225 \\
\hline AKS3 & 0.151 & 0.470 & 0.774 & 0.353 & 0.106 & 0.246 \\
\hline AKS4 & 0.166 & 0.417 & 0.780 & 0.322 & 0.096 & 0.241 \\
\hline AKS5 & 0.271 & 0.510 & 0.854 & 0.402 & 0.224 & 0.343 \\
\hline SN1 & 0.217 & 0.398 & 0.391 & 0.881 & 0.199 & 0.185 \\
\hline SN2 & 0.213 & 0.323 & 0.323 & 0.860 & 0.159 & 0.106 \\
\hline SN3 & 0.198 & 0.464 & 0.414 & 0.758 & 0.156 & 0.125 \\
\hline DJ1 & 0.918 & 0.258 & 0.300 & 0.291 & 0.616 & 0.487 \\
\hline DJ2 & 0.857 & 0.249 & 0.220 & 0.195 & 0.493 & 0.425 \\
\hline DJ3 & 0.888 & 0.163 & 0.183 & 0.163 & 0.614 & 0.548 \\
\hline DJ4 & 0.843 & 0.176 & 0.172 & 0.224 & 0.614 & 0.553 \\
\hline PJ1 & 0.540 & 0.048 & 0.142 & 0.142 & 0.812 & 0.339 \\
\hline PJ2 & 0.591 & 0.063 & 0.123 & 0.120 & 0.870 & 0.306 \\
\hline PJ3 & 0.462 & 0.033 & 0.082 & 0.158 & 0.822 & 0.329 \\
\hline PJ4 & 0.586 & 0.163 & 0.265 & 0.254 & 0.798 & 0.489 \\
\hline PJ5 & 0.475 & -0.040 & 0.154 & 0.144 & 0.649 & 0.496 \\
\hline IJ1 & 0.477 & 0.132 & 0.337 & 0.152 & 0.343 & 0.779 \\
\hline IJ2 & 0.425 & 0.107 & 0.202 & 0.102 & 0.263 & 0.756 \\
\hline IJ3 & 0.509 & 0.163 & 0.251 & 0.096 & 0.452 & 0.843 \\
\hline IJ4 & 0.425 & 0.195 & 0.342 & 0.184 & 0.369 & 0.839 \\
\hline
\end{tabular}




\begin{tabular}{|c|c|c|c|c|c|}
\hline \multicolumn{6}{|c|}{ Table A-6: Descriptive statistics } \\
\hline Construct & Items & Mean & SD & Skewness & Kurtosis \\
\hline \multirow{5}{*}{$\begin{array}{l}\text { Attitude toward } \\
\text { Knowledge Sharing } \\
\text { (AKS) }\end{array}$} & AKS1 & 4.427 & 0.662 & -1.019 & 1.102 \\
\hline & AKS 2 & 4.164 & 0.811 & -0.619 & -0.119 \\
\hline & AKS 3 & 4.373 & 0.667 & -1.061 & 2.374 \\
\hline & AKS 4 & 4.427 & 0.611 & -0.566 & -0.589 \\
\hline & AKS 5 & 4.350 & 0.620 & -0.401 & -0.656 \\
\hline \multirow{4}{*}{$\begin{array}{l}\text { Distributive Justice } \\
\text { (DJ) }\end{array}$} & DJ1 & 3.564 & 0.975 & -0.733 & -0.052 \\
\hline & DJ2 & 3.555 & 0.942 & -0.820 & 0.443 \\
\hline & DJ3 & 3.500 & 1.018 & -0.550 & -0.265 \\
\hline & DJ4 & 3.573 & 0.926 & -0.685 & 0.130 \\
\hline \multirow{5}{*}{$\begin{array}{l}\text { Procedural Justice } \\
\text { (PJ) }\end{array}$} & PJ1 & 3.491 & 0.986 & -0.623 & 0.035 \\
\hline & PJ2 & 3.464 & 1.017 & -0.583 & -0.245 \\
\hline & PJ3 & 3.436 & 1.069 & -0.580 & -0.269 \\
\hline & PJ4 & 3.827 & 0.930 & -0.783 & 0.467 \\
\hline & PJ5 & 3.141 & 1.074 & -0.173 & -0.668 \\
\hline \multirow{4}{*}{$\begin{array}{l}\text { Interactional Justice } \\
\text { (IJ) }\end{array}$} & IJ1 & 3.627 & 0.804 & -0.501 & 0.353 \\
\hline & IJ2 & 3.345 & 0.901 & -0.323 & -0.559 \\
\hline & $\mathbf{I J 3}$ & 3.764 & 0.799 & -0.688 & 1.071 \\
\hline & IJ4 & 3.745 & 0.799 & -0.648 & 0.713 \\
\hline \multirow{3}{*}{$\begin{array}{l}\text { Subjective Norm } \\
\text { (SN) }\end{array}$} & SN1 & 18.409 & 5.289 & -0.516 & -0.156 \\
\hline & SN2 & 17.305 & 4.844 & -0.101 & -0.509 \\
\hline & SN3 & 15.691 & 4.232 & 0.299 & -0.112 \\
\hline
\end{tabular}




\section{Glossary}

Average variance extracted (AVE) measures the amount of variance that is captured by the construct in relation to the amount of variance due to measurement error.

Common method variance (CMV) is the variance that is attributable to the measurement method rather than to the constructs the measures represent.

Comparative fit index (CFI) analyzes the model fit by examining the discrepancy between the data and the hypothesized model, while adjusting for the issues of sample size inherent in the chisquared test of model fit, and the normed fit index.

Construct validity refers to the extent to which operationalizations of a construct do actually measure what the theory says they do.

Confirmatory factor analysis (CFA) is a special form of factor analysis that is used to test whether measures of a construct are consistent with a researcher's understanding of the nature of that construct (or factor).

Convergent validity refers to the degree to which a measure is correlated with other measures that it is theoretically predicted to correlate with.

Latent variables are variables that are not observed directly but are rather inferred through a mathematical model from other variables that are observed (directly measured).

LISREL structural equation modeling software is used typically for performing confirmatory factor analysis

Normed fit index (NFI) analyzes the discrepancy between the chi-squared value of the hypothesized model and the chi-squared value of the null model. However, this NFI was found to be very susceptible to sample size. The non-normed fit index (NNFI) resolves some of the issues of sample size.

Reliability refers to the consistency of a measure. A measure is said to have a high reliability if it produces consistent results under consistent conditions.

Root mean square error of approximation (RMSEA) analyzes the discrepancy between the hypothesized model, with optimally chosen parameter estimates, and the population covariance matrix.

Skewness is a measure of the asymmetry of the probability distribution of a real-valued random variable. 


\section{Biographies}

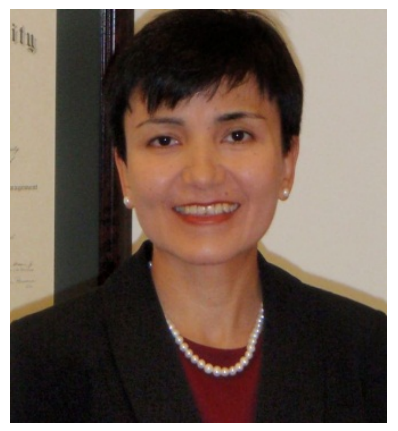

Bashorat Ibragimova received her $\mathrm{PhD}$ in IS from the University of North Texas and an MBA in International Management from Baylor University. Her research interests include cross-cultural studies of IT, knowledge management, organizational factors, cybersecurity and egovernment issues. Her work has appeared in the Informing Science Journal: the International Journal of an Emerging Transdiscipline, Business Process Management Journal, Proceedings of the International Conference on Information Systems, Proceedings of Decision Science Institute and Proceedings of the Americas Conference on Information Systems.

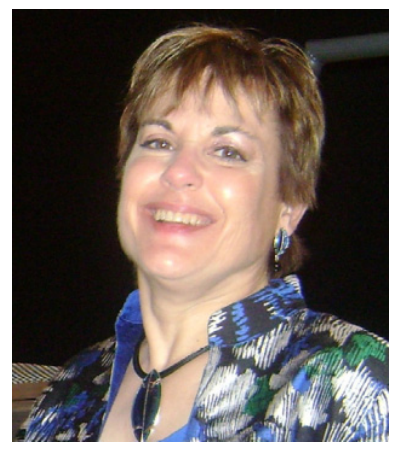

Sherry D. Ryan is an Associate Professor of Information Technology and Decision Sciences at the University of North Texas. She received her Ph.D. in IS from the University of Texas at Arlington and an MBA from the University of Southern California. Prior to returning to academia she worked for IBM, teaching courses and speaking at national conferences. Her research interests include IT human resource issues, knowledge management, and social media. Her work has appeared in journals including Journal of Management Information Systems, Decision Support Systems, and Informing Science: the International Journal of an Emerging Transdiscipline

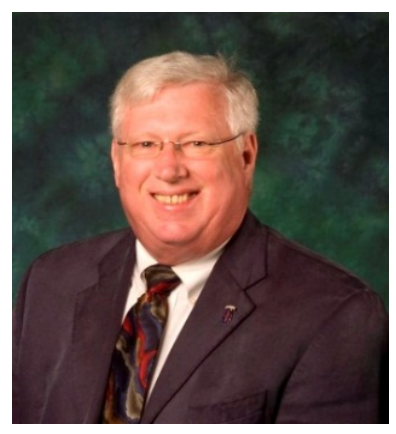

John C. Windsor is a professor of Information Systems and former Director of the Information Systems Research Center at the University of North Texas. He received his Ph.D. from Georgia State University. He has published over six books and 60 articles in such journals as Data Base, IIE Transactions, Information \& Management and Computers \& Security. His research interests include software and data engineering, systems security, collaborative computing, and the organizational impact of information technology.

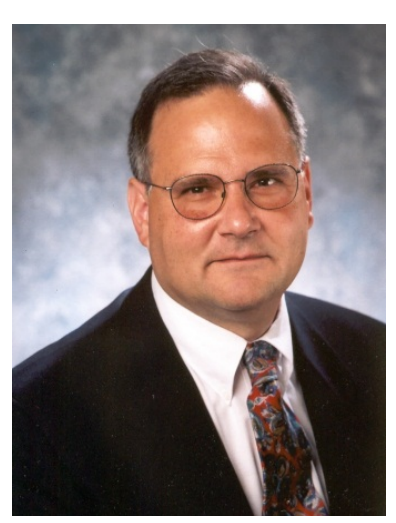

Victor R. Prybutok is a Regents Professor of Decision Sciences in the Information Technology and Decision Sciences Department and Associate Dean of the Toulouse Graduate School at the University of North Texas. He received, from Drexel University, his B.S. with High Honors in 1974, a M.S. in Bio-Mathematics in 1976, a M.S. in Environmental Health in 1980, and a Ph.D. in Environmental Analysis and Applied Statistics in 1984. Dr. Prybutok is an American Society for Quality certified quality engineer, certified quality auditor, certified manager of quality / organizational excellence, and an accredited professional statistician (PSTAT®) by the American Statistical Association. Dr. Prybutok has authored over 100 journal articles, several book chapters, and more than 100 conference presentations in information systems measurement, quality control, risk assessment, and applied statistics. 